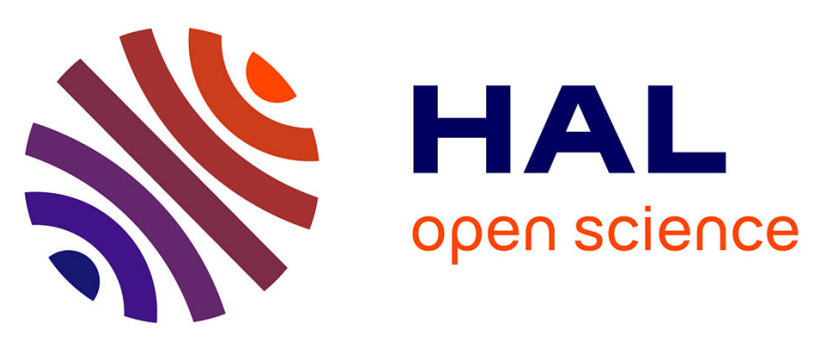

\title{
Factors Underlying the Narrow Distribution of the Mediterranean Annual Plant Arenaria provincialis (Caryophyllaceae)
}

Sami Youssef, Alex Baumel, Errol Véla, Marianick Juin, Estelle Dumas, Laurence Affre, Thierry Tatoni

\section{To cite this version:}

Sami Youssef, Alex Baumel, Errol Véla, Marianick Juin, Estelle Dumas, et al.. Factors Underlying the Narrow Distribution of the Mediterranean Annual Plant Arenaria provincialis (Caryophyllaceae). Folia Geobotanica, 2011, 46 (4), pp.327 - 350. 10.1007/s12224-011-9101-1 . hal-01791891

\section{HAL Id: hal-01791891 \\ https://hal.science/hal-01791891}

Submitted on 29 May 2018

HAL is a multi-disciplinary open access archive for the deposit and dissemination of scientific research documents, whether they are published or not. The documents may come from teaching and research institutions in France or abroad, or from public or private research centers.
L'archive ouverte pluridisciplinaire HAL, est destinée au dépôt et à la diffusion de documents scientifiques de niveau recherche, publiés ou non, émanant des établissements d'enseignement et de recherche français ou étrangers, des laboratoires publics ou privés. 


\section{Factors Underlying the Narrow}

Distribution of the Mediterranean

Annual Plant Arenaria provincialis

(Caryophyllaceae)

\section{Sami Youssef, Alex Baumel, Errol Véla, Marianick Juin, Estelle Dumas, Laurence Affre \& Thierry Tatoni}

\section{Folia Geobotanica}

Journal of the Institute of Botany, Academy of Sciences of the Czech Republic

ISSN 1211-9520

Volume 46

Number 4

Folia Geobot (2011) 46:327-350

DOI 10.1007/s12224-011-9101-1

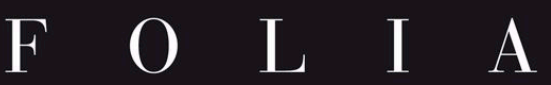 GEOBOTANICA}

A Journal of Plant Ecology and Systematics

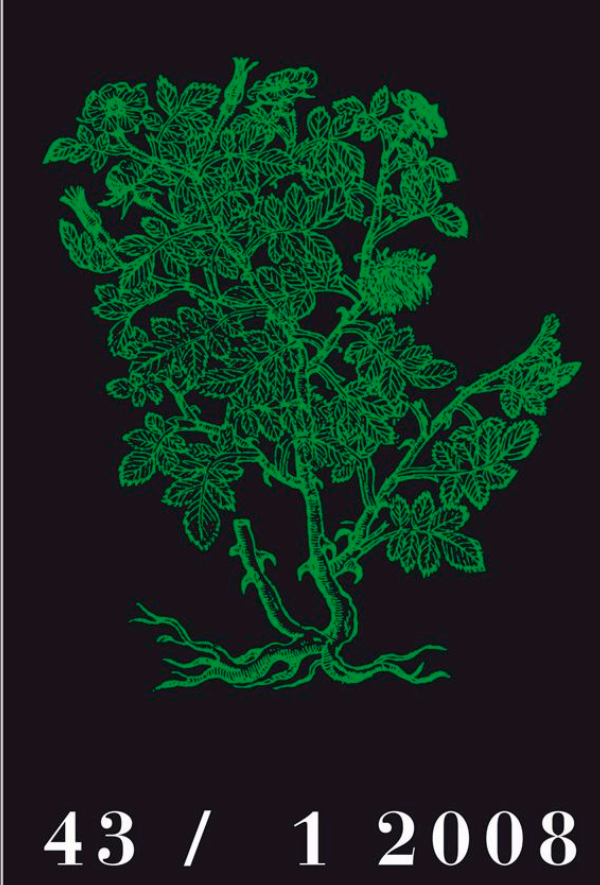

INSTITUTE OF BOTANY, ACADEMY OF SCIENCES OF THE CZECH REPUBLIC 
Your article is protected by copyright and all rights are held exclusively by Institute of Botany, Academy of Sciences of the Czech Republic. This e-offprint is for personal use only and shall not be self-archived in electronic repositories. If you wish to selfarchive your work, please use the accepted author's version for posting to your own website or your institution's repository. You may further deposit the accepted author's version on a funder's repository at a funder's request, provided it is not made publicly available until 12 months after publication. 


\title{
Factors Underlying the Narrow Distribution of the Mediterranean Annual Plant Arenaria provincialis (Caryophyllaceae)
}

\author{
Sami Youssef • Alex Baumel • Errol Véla • Marianick Juin • \\ Estelle Dumas • Laurence Affre • Thierry Tatoni
}

(C) Institute of Botany, Academy of Sciences of the Czech Republic 2011

\begin{abstract}
The factors responsible for the patterns of niche differentiation and narrow endemism have rarely been investigated in annual Mediterranean plants. This topic was addressed here by performing comparative studies on realized niches, regional occupancy, global biogeographical distribution and seed traits of a set of Arenaria (Caryophyllaceae) species inhabiting southern Provence (SE France), focusing in particular on Arenaria provincialis, a narrow endemic restricted to the hills and modest calcareous mountains around the city of Marseille. Field studies were carried
\end{abstract}

Electronic supplementary material The online version of this article (doi:10.1007/s12224-011-9101-1) contains supplementary material, which is available to authorized users.

S. Youssef $\cdot$ A. Baumel $(\bowtie) \cdot$ M. Juin $\cdot$ E. Dumas $\cdot$ L. Affre $\cdot$ T. Tatoni Université Paul Cézanne, Aix-Marseille III, UMR CNRS 6116/IRD UMR-193 Institut Méditerranéen d'Ecologie et de Paléoécologie, IMEP Bat. Villemin Europole de l'Arbois, BP80, 13545 Aix en Provence Cedex 04, France

e-mail: alex.baumel@univ-cezanne.fr

URL: www.imep-cnrs.com

S. Youssef

e-mail: sami.youssef@hotmail.com

M. Juin

e-mail: m.juin@univ-cezanne.fr

E. Dumas

e-mail: estelle.dumas@univ-cezanne.fr

L. Affre

e-mail: laurence.affre@univ-cezanne.fr

T. Tatoni

e-mail: thierry.tatoni@univ-cezanne.fr

E. Véla

Université Montpellier-2, UMR AMAP (botAnique et bioinforMatique de l'Architecture des Plantes), TA A-51/PS2, Bd. de la Lironde, 34398 Montpellier cedex 5, France e-mail: errol.vela@cirad.fr 
out from 2008 to 2009 at 624 sites in the limestone mountains where Arenaria species are likely to occur. The Arenaria species occurring in southern Provence vary greatly in their patterns of regional occupancy and their biogeographical distribution. Multivariate analysis of the realized niche showed that they have some similar limiting environmental factors in common, but they do not all occupy the same habitats. Studies on the fruits and seeds showed that the endemic $A$. provincialis has a larger seed than its congeners and a capsule that remains closed and falls from the plant at maturity. This well-differentiated diaspore specific to $A$. provincialis may be responsible for the limited dispersal capacity of this species. Phylogenetic analyses showed that $A$. provincialis is not closely related to the other taxa inhabiting southern Provence, but rather to Arenaria occurring in highland areas in the south of France. The restricted pattern of distribution of A. provincialis is probably due to the past isolation event from which it originated and to its limited dispersal capacity, rather than resulting from its ecological niche range.

Keywords Biogeography $\cdot$ Diaspore $\cdot$ Endemism $\cdot$ Niche $\cdot$ Phylogeny

Seed $\cdot$ Speciation

\section{Introduction}

Understanding why some species have a restricted geographic range while other closely related species show widespread patterns of distribution is a topic that has fascinated many evolutionary ecologists and biologists (Brown and Stevens 1996; Kunin and Gaston 1997; Webb and Gaston 2003). Restricted endemic plant species may have a narrower range of ecological tolerance, more specialized ecological requirements, and/or poorer dispersal abilities and lower reproductive investments (Gaston 1994; Kunin and Gaston 1997; Debussche and Thompson 2003; Lavergne et al. 2004; Becker 2010) than their more widespread congeners. The prevalence of endemic plants in habitats where there is a slow rate of plant succession is also a well-known feature of the Mediterranean and the Alps (Médail and Verlaque 1997; Tribsch and Schönswetter 2003; Thompson 2005). These extreme or azonal habitats, i.e., rocky places, cliffs and steep slopes, may have promoted the persistence of endemic plants and enhanced specific traits (Thompson 2005). In addition, some macro-ecological hypotheses have been put forward suggesting that narrowly endemic species are less able than more widespread species to make use of the resources available and/or to disperse (Brown 1984; Hanski et al. 1993). Rossetto and Kooyman (2005) have shown, for example, that the current distribution of the paleoendemic tree Eidothea hardeniana (Proteaceae) was limited by its dispersal potential rather than by habitat availability or reproductive failure. Another hypothesis is that some narrowly endemic plants may be relatively young species that have not yet had time to expand their range (Walck et al. 2001). Lesica et al. (2006) have reported, for example, that seven narrowly endemic plants were 2-10 times more abundant locally than their widespread congeners in the Rocky mountains. These authors attributed this pattern to the unusual habitats of narrow endemics, but they also suggested that recent speciation events may have occurred, which would mean that these endemics have not yet reached their full geographical 
range. It therefore emerges from the literature that studies on the causes of restricted distribution should take ecological and phylogenetic factors into account. In the context of studies on the causes and consequences of plant rarity (Rabinowitz 1981; Chown 1997), comparisons between closely related taxa have attempted to minimize the confounding effects of various phylogenetic constraints (Silvertown and Dodd 1996): many comparisons have therefore been carried out on large sets consisting of many species (Gitzendanner and Soltis 2000; Lavergne et al. 2004) as well as on smaller sets mostly consisting of a single pair of species (Baskin et al. 1997; Walck et al. 2001; Debussche and Thompson 2003)

This study aimed therefore to determine the ecological and biological differences existing among a set of Arenaria (Caryophyllaceae) species occurring in southern Provence (SE France), which differ considerably in their patterns of regional occupancy and global biogeographical distribution. One of them is A. provincialis Chater \& G. Halliday, an annual plant occurring only in the hills around the city of Marseille (Véla et al. 2008). To the best of our knowledge, no studies have yet dealt with niche differentiation and narrow endemism in Mediterranean annual plants. It was proposed in particular to address the following three points. Firstly, niche breadths, regional occupancies and global biogeographical distribution were compared among all the Arenaria species of southern Provence and between $A$. provincialis and its ecologically similar co-occurring species on the basis of a huge data set consisting of 624 relevés collected in all the low mountains of southern Provence. The aim of these comparisons was to determine the relationships between the ecological range and the restricted distribution of $A$. provincialis. Secondly, the diaspore traits of a subset of Arenaria species were compared in order to examine the possibility that $A$. provincialis may have a limited dispersal capacity. Lastly, the phylogenetic positions of southern Provençal Arenaria species were drawn up to investigate whether A provincialis originated by diverging from a local sister species or as the result of a past isolation event.

\section{Material and Methods}

\section{Study Area}

Field studies were conducted in southern Provence (southeastern France). Southern Provence has several ranges of moderately high limestone mountains $(<1,150 \mathrm{~m}$ above sea level), which shelter some rare or endemic plant taxa (Molinier 1934; Loisel 1976; Véla et al. 2008; Crouzet et al. 2009; Youssef et al. 2010). Along with the increase in the human population density occurring around the Mediterranean basin, natural habitats in Provence are being affected by a combination of urban sprawl (in the Aix-Marseille urban area, for example), land abandonment and habitat fragmentation (Barbero et al. 1990; Tatoni et al. 2004; Dumas et al. 2008). The present study area covers the small limestone mountain ranges running from the coastline to approximately $60 \mathrm{~km}$ inland, namely the hills around Marseille (the Calanques, Carpiagne, Etoile, Grand Caunet and Cap Canaille, Nerthe), Sainte Victoire, Sainte Baume, the Alpilles, and the southern part of the Luberon. Some additional study sites were set up on Mont Ventoux and 
in the Verdon mountains (Fig. 1). It is worth noting that this study covered practically all the hills and low mountains in southern Provence where Arenaria taxa are present (Fig. 1).

\section{The Pattern of Occurrence of Arenaria Species}

Arenaria provincialis is a small endemic winter annual plant occurring only in the limestone hills around the city of Marseille (Véla et al. 2008). It grows in open habitats such as steep scree slopes, ledges, cracks and summit crests, ranging from xero-thermic littoral southwestern sites to cold, northeastern mountain sites (Crouzet 1966; Baumel et al. 2009). Arenaria provincialis is protected by French law, European directives and international conventions. In addition, it was defined by the IUCN as a "Rare" species, based on the former threat criteria (Walter and Gillet 1998), before being recently redefined as a "Nearly Threatened" species, based on the latest red list assessment criteria (Véla et al. 2008). The name Arenaria provincialis is accepted in Flora Europaea (Chater and Halliday 1964) as the correct name for this taxon in the genus Arenaria, replacing Gouffeia arenarioides DC., which is treated as a synonym.

Arenaria aggregata (L.) Loisel. is a perennial plant forming a loose cushion. It inhabits several western Mediterranean mountains, from northwestern Algeria to northwestern Italy, as well as the Iberian Peninsula (Quézel and Santa 1962; Chater and Halliday 1964; Pignatti 1982). In our study area, it occurs frequently on

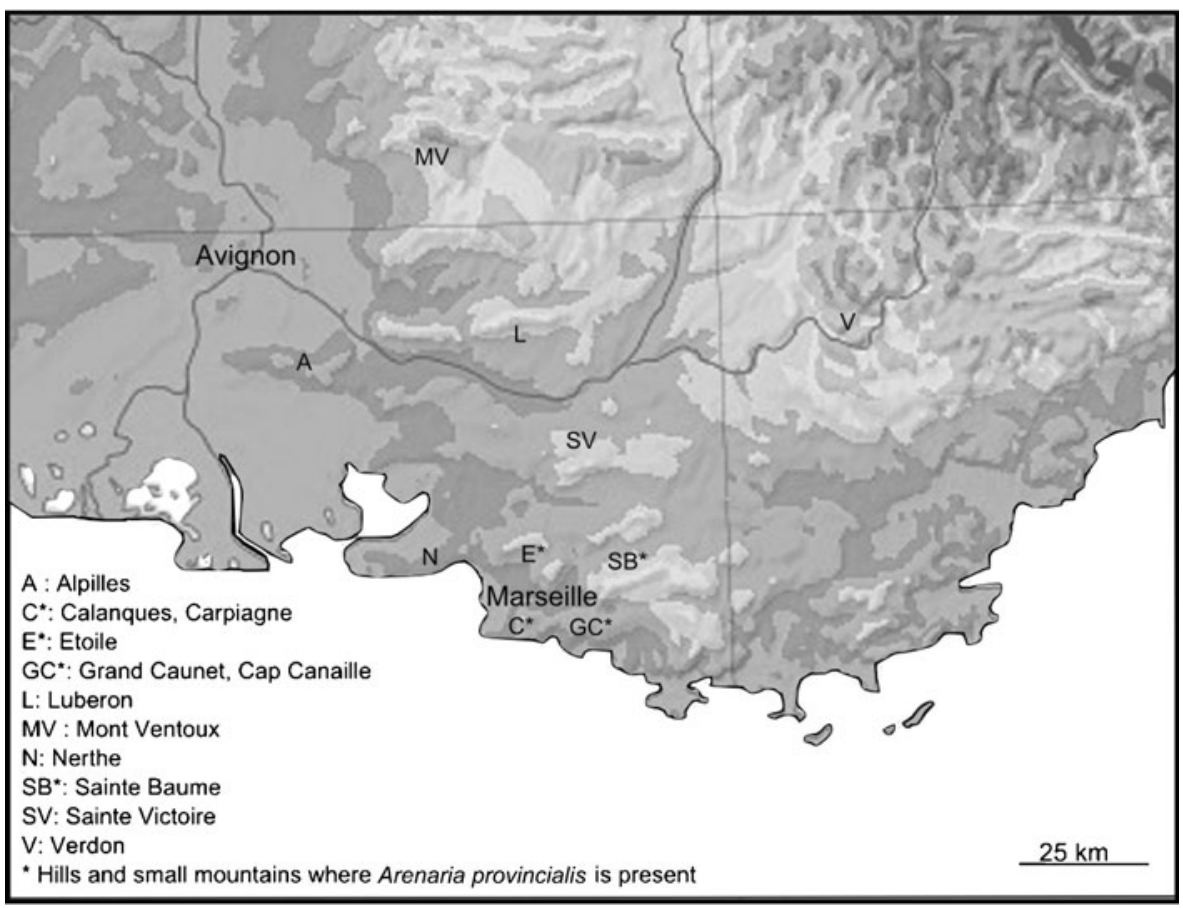

Fig. 1 Map of the study area in southern Provence giving the positions of our sample locations 
mountain summits (i.e., in crest habitats), in open areas in rocky limestone or dolomitic habitats, and almost never in lowland areas (Rameau et al. 2008).

Arenaria serpyllifolia L. occurs in Europe, temperate Asia, North Africa, New Zealand and North America (Grime et al. 1988). It is a small winter annual plant with wide range of habitats. It has frequently been reported to grow in open places such as limestone rock outcrops, walls, cliffs, and scree slopes, and is also commonly encountered in disturbed habitats (Chater and Halliday 1964; Grime et al. 1988). In the literature, A serpyllifolia has been reported to be both biannual and perennial (Chater and Halliday 1964). However, in our study area, it is always an annual plant.

Arenaria modesta Dufour is another small annual winter-flowering plant growing in open areas. It is a north-western Mediterranean species occurring in southern France and eastern Spain (Chater and Halliday 1964; López González 1990). This species is thought to be a rare species (Cruon 2008), and its pattern of distribution in southern Provence is highly fragmented. In our study area, it was encountered only in rocky dolomitic habitats.

Arenaria grandiflora L. is a perennial plant occurring on cliffs and bare limestone rocks in the southern and central mountains of Europe and also in north-African mountains (Sáez et al. 2002). In France, it occurs frequently in mountainous regions and very rarely in lowland regions (Chater and Halliday 1964). In southern Provence, it is also taken to be a rare species, because it occurs only on three mountains (Mont Ventoux, Sainte Victoire and Sainte Baume), in open rocky places at an altitude of approximately 1,000 meters.

\section{Floristic and Habitat Variables}

The study area comprised the entire geographical range of $A$. provincialis in the region under investigation. Field studies were carried out from 2008 to 2009 throughout the limestone mountains of southern Provence. To include larger numbers of occurrences of other Arenaria species, we extended the sampling area beyond this range to some limestone mountains of northern Provence (Fig. 1). Our field studies were restricted, however, to herbaceous, fruticose, mattoral formations and rocky habitats (scree slopes, cracks, ledges, and cliffs), where Arenaria species are likely to occur, based on previous studies and our own experience. Artificial habitats, agricultural areas (cultivated lands), forests and wetlands were not explored because Arenaria species do not occur in these habitats in southern Provence. Great care was taken to obtain an accurate picture of the regional occupancy of Arenaria taxa in the study area. All in all, a large proportion of all the open rocky habitats in southern Provence were visited.

The study area was then divided into 85 grid cells of $5 \times 5 \mathrm{~km}$ (total extension= $2,125 \mathrm{~km}^{2}$ ), which included the most hills and low mountain ranges in southern Provence; Arenaria provincialis was found only in 21 of the grid cells (total rangesize distribution $=525 \mathrm{~km}^{2}$ ). Two to twenty sample locations were subsequently selected in each grid cell, depending on whether $i$ ) Arenaria species were present, $i$ ) access was possible, and iii) low vegetation cover habitats (open habitats) were involved. Each $5 \times 5 \mathrm{~km}$ grid cell contained at least one sample location at which at least one Arenaria species was present, as well as many other sample locations in 
low vegetation cover habitats containing no Arenaria species. This approach consisting in noting the presence/absence of Arenaria was adopted to compare the environmental and floristic characteristics between sample locations where Arenaria were present and absent, and thus to delimit the realized niches of the Arenaria species in question and distinguish clearly between them.

At each sample location, a list of the plant species present (seed plants and ferns) and habitat variables was drawn up in circular $100-\mathrm{m}^{2}$ areas as described by Gachet et al. (2005). The following habitat variables were recorded: GPS coordinates, altitude, aspect (coded with a four-level scale, from north- to south- facing), bare soil cover, gravel cover $(<20 \mathrm{~cm})$, stone cover $(>20 \mathrm{~cm}$, loose stones), rock cover $(>20 \mathrm{~cm}$, fixed rocks), and each vegetation stratum was defined as consisting of herbaceous plants $(<0.5 \mathrm{~m})$, low shrubs $(0.5$ to $2 \mathrm{~m})$, high shrubs $(2$ to $4 \mathrm{~m})$, and trees $(>4 \mathrm{~m})$. To quantify the substrate and vegetation cover, the following rates of coverage were used: (1) $<10 \%$, (2) $10 \%-25 \%$, (3) $25 \%-50 \%$, (4) $50 \%-75 \%$ and (5) $>75 \%$. All sampling campaigns were carried out between the months of March and July to identify a maximum number of plant species.

All in all, 624 sample locations were visited: Arenaria taxa were found to be present at 358 of these sites: 156 of the sites included A. provincialis, 153 included A. serpyllifolia, 59 included $A$. aggregata, 39 included $A$. modesta and 19 included A. grandiflora. Arenaria species were absent at 266 of the sample locations.

\section{Climatic and GIS Variables}

The climatic data set contained 19 bioclimatic variables available in the Worldclim database (Hijmans et al. 2005). Climatic data corresponding to each of the GPS coordinates were obtained from the Worldclim database using the Diva GIS program (Hijmans et al. 2001). Principal component analysis (PCA) was then performed to position the sampled locations in the climatic space (ADE4 package, R Development Core Team 2009). The two first axes were used as independent variables for further multivariate analysis of the niche, as described below. The first climatic PCA axis (coded climate axis 1) was positively correlated with the annual precipitation and negatively correlated with the temperature during the warmest and coldest months. The second axis (coded climate axis 2) was positively correlated with the seasonality of the temperature.

GIS variables were the "slope", "hillshade" (the relief shade) and "landscape plant cover" (land cover) calculated from 50-meter resolution maps using a GIS software program. The "landscape plant cover" variable included urban areas, bare rocks, areas sparsely covered with vegetation and grasslands, sclerophyllous vegetation, transitional woodland-shrubs, and forest, which were coded from 0 to 5 , respectively, to describe the plant-cover gradient ranging from open to forested areas. This map was obtained from the CRIGE-PACA site (http://www.crige-paca. org/) developed using the Landsat 7 ETM+satellite.

\section{Measures and Observation of Diaspore Traits}

Seeds and fruits were collected from 25 to 35 randomly selected mature individuals per species. In order to rule out the occurrence of site-related effects, A. provincialis, 
A. aggregata, $A$. serpyllifolia and $A$. grandiflora plants were sampled in the same area on a limestone substrate, whereas the $A$. modesta plants originated from the nearest dolomitic location. The following parameters were measured: number of seeds per capsule, seed set per individual and seed mass (weight of 1,000 seeds) according to Cornelissen et al. (2003). In the case of A. ciliata, A. hispida and A. cinerea, which were difficult to find on the field, only one population was studied and only seed mass was measured. Because A. modesta, A. cinerea and A. provincialis are rare and/or protected species, we collected only $50 \%$ of the capsules of each individual plant. Pairwise Kruskal-Wallis tests were carried out to test whether the seed traits differed between Arenaria species (STAT package, R Development Core Team 2009). The capsules of several individuals belonging to each of the eight species were checked in situ, noting whether the capsules were open or closed and firmly attached or not to the calyx: the plants were gently shaken to determine the mobility of the diaspores (seeds or capsules) falling from the plant to the soil.

\section{Multivariate Analysis of Realized Niches}

To delimit the boundaries of the realized niches (Hutchinson 1957) of Arenaria in southern Provence, an Outlying Mean Index analysis (OMI, Dolédec et al. 2000) was performed. This method was recently preferred to classical two-table coupling methods to $i$ ) address the question of niche separation and species distribution along environmental gradients (Choler and Michalet 2002; Thuiler et al. 2004; Tsiftsis et al. 2008), and ii) to examine the relationships between niche position, niche breadth, geographic range and/or assemblage diversity (Heino and Soininen 2006; Soininen and Heino 2007). The OMI method measures the position of a niche (expressed in terms of a marginality index) in a species habitat distribution, i.e., the distance between the mean habitat conditions used by a species and the mean habitat conditions across the study area. Species that obtain high OMI indices (marginality indices) therefore have marginal niches (i.e., they occur in an atypical habitat in the study area), and those that obtain low OMI indices have non-marginal niches (i.e., they occur in typical habitats in the study area). OMI analysis also measures the range of each species in the environmental space, i.e., their niche breadth. High niche breadth values mean that the species is distributed over a wide range of environments (generalist species), while low values mean that the species is distributed within a restricted range of environments (specialist species). Approaches of this kind have been recently used to explore ecological niches (Calenge and Basille 2008). Niche definition is a highly debated topic (Silvertown et al. 2001); in line with Choler and Michalet (2002), the "niche attributes" were used here to compare the position and range of a subset of species in a multivariate environmental space taken to be representative of all the realized niches of the species present.

In this study, $A$. provincialis was compared with its congeners and ecologically similar co-occurring species in terms of the niche parameters (marginality and breadth), regional occupancy in the study area (the "regional scale") and on a coarser scale, the global biogeographical distribution (the "global scale"). Regional occupancy was measured in terms of the number of grid cells $(5 \times 5 \mathrm{~km})$ in which A. provincialis, its congeners and its ecologically similar co-occurring species were 
detected. Biogeographical distribution sensu Pignatti (1982) corresponds to the relative size of the biogeographical region in which species have been reported to occur in the literature (Quézel and Santa 1962; Chater and Halliday 1964; Pignatti 1982; López González 1990). Niche parameter values, regional occupancy and biogeographical distribution range were obtained for 32 species, namely the Arenaria taxa occurring in southern Provence and the most frequent plant species co-occurring with A. provincialis, based on the literature (Molinier 1934; Loisel 1976; Baumel et al. 2009) and our own data.

All multivariate analyses were performed with the ADE-4 packages (Thioulouse et al. 1997) provided with the R 2.10 statistical software program (R Development Core Team 2009). Species with frequencies inferior to $1 \%$ were removed from the analysis. The final floristic table contained 624 sample locations and 254 species. The table of explanatory data contained 624 locations and 17 variables. The statistical significance of the niche marginality and the niche breadth indices was tested by performing random permutation tests (1,000 replicates). Correlations between niche breadth and regional geographical range were tested by performing Pearson's rank tests (STAT package, R Development Core Team 2009).

\section{Phylogenetic Analysis}

Most of the molecular data used here have been recently published in studies on the phylogeny of Caryophyllaceae (Fior et al. 2006; Fior and Karis 2007). However, new sequencing data were also obtained on $A$. provincialis, A. modesta, $A$. serpyllifolia, A. aggregata, A. grandiflora, A. cinerea DC., A. ermarginata, $A$. conimbricensis Brot., and A. hispida L. The five Arenaria occurring in southern Provence were sampled, and two taxa from other highland habitats in southern France were added: $A$. cinerea from Verdon and $A$. hispida from the Causses region. Because we had the opportunity to obtain specimens of $A$. conimbricensis and $A$. ermarginata, we decided to add them in the analysis to improve the phylogenetic knowledge about Arenaria. Genbank accessions are summarized in Electronic Supplementary Material 1.

The locations of the samples were as follows: Arenaria aggregata: Massif de l'Etoile, col St Anne, near Mimet (Bouches du Rhône, France), N 43²4'30", E 5²9'07"; Arenaria cinerea: Verdon, near La Palud sur Verdon (Alpes de Haute Provence, France), N 4347'17", E 6²2'34"; Arenaria conimbricensis: El portel de l'infern, parc natural de la Tinença de Benifassà (Spain), N 4042'12", W 0¹1'47"; Arenaria ermarginata: Lac noir (Algeria), N 36 51'14", E 8¹2'17"; Arenaria

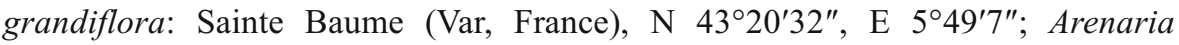
hispida: Col du vent (Hérault, France), N 4345'03", E $3^{\circ} 27^{\prime} 49^{\prime \prime}$; Arenaria modesta: Massif de l'Etoile, col St Anne, near Mimet (Bouches du Rhône, France), N 43²4'30", E 5²9'07"; Arenaria provincialis: near Carnoux (Bouches du Rhône, France), N 4316'22", E 5³5'06"; Arenaria serpyllifolia: Massif de l'Etoile, col St Anne, near Mimet (Bouches du Rhône, France), N 43²4'30", E 5²9'07"; Moehringia intermedia: Gorges du Verdon (Alpes de Haute Provence, France), N $43^{\circ}$ 47'17', E 6 23'44". Voucher specimens are located in A. Baumel's herbarium at Europole de l'Arbois, Aix en Provence, France. 
Because some of the data obtained have been published in Fior et al. (2006) and Fior and Karis (2007), the presentation of the phylogenetic analysis has been restricted here to Alsineae taxa belonging to the two monophyletic sister groups $\mathrm{B}$ and $\mathrm{C}$ described by Fior et al. (2006). The B group was used as the outgroup because preliminary analyses showed that the taxa studied here belong to the $\mathrm{C}$ group.

Leaves and stems of Arenaria taxa were dried with silica gel and ground in liquid nitrogen before DNA extraction was performed. Total DNA was extracted (Doyle and Doyle 1987) and precipitated in a 0.6 M sodium acetate ethyl alcohol solution and washed with $70 \%$ ethyl alcohol before being resuspended in pure $\mathrm{H}_{2} \mathrm{O}$. The terminal part of the matK gene was amplified by performing PCR using the primers $390 \mathrm{~F}$ (CGATCTATTCATTCAATATTTC) and 1440R (GTGTTTACGAGCYAAAGTTC). PCRs were carried out in $100 \mu \mathrm{l}$ volumes containing $10 \mathrm{mM}$ TrisHCl $(\mathrm{pH} 9), 50 \mathrm{mM}$ $\mathrm{KCl}, 1.75 \mathrm{mM} \mathrm{MgCl} 2,0.6 \mathrm{mg} / \mathrm{ml} \mathrm{BSA}, 0.1 \%$ Triton X100, $0.2 \mathrm{mM}$ of each primer, $0.4 \mathrm{mM}$ dNTPs, $5 \mathrm{U}$ Taq (Taq CORE Kit, Q-BIOgene) and $4 \mu$ l of DNA template at a concentration ranging from 126 to $740 \mathrm{ng} / \mu \mathrm{l}$. The PCR program was: 2 minutes at $94^{\circ} \mathrm{C}$, followed by 30 PCR cycles $\left(45\right.$ seconds at $94^{\circ} \mathrm{C}, 45$ seconds at $48^{\circ} \mathrm{C}$ and 2 minutes at $72^{\circ} \mathrm{C}$ ), ending with 5 minutes at $72^{\circ} \mathrm{C}$. PCR products were sequenced directly by the company AGOWA. Whenever possible, two samples per taxon were analyzed, but because no strong haplotypic divergences were detected, only one sequence was used for each taxon to make the presentation of the results as clear as possible. Sequences were carefully checked on chromatograms with the MEGA4 software program (Tamura et al. 2007).

Sequences were aligned using the Clustal W program (Higgins et al. 1992) before being converted directly into Nexus format in the MEGA4 program. The final alignment including 49 taxa had a length of $705 \mathrm{bp}$, and contained 116 parsimoniously informative sites. To obtain a phylogenetic tree, we first drew up a maximum parsimony tree by performing a heuristic search with PAUP* 4.0 $($ Swofford 2003) $($ start $=$ stepwise, addseq $=$ random, nreps $=1,000$, randomize $=$ addseq, swap $=$ tbr, multrees $=$ yes $)$ and then used one of the most parsimonious trees as the initial tree in a maximum likelihood (ML) analysis performed with the PHYML 3.0 software program (Guindon and Gascuel 2003). The evolutionary model was chosen with Modeltest 3.7 (Posada and Crandall 1998). The Akaike information criterion (AIC) was used to select the general time reversible (GTR) nucleotide substitution model with a gamma substitution rate distribution. PHYML was subsequently allowed to optimize the initial values of the GTR model. The parameters thus obtained were $\mathrm{A}<->\mathrm{C}=1.34750, \mathrm{~A}<->\mathrm{G}=1.47668, \mathrm{~A}<->\mathrm{T}=$ $0.33368, \mathrm{C}<->\mathrm{G}=1.19750, \mathrm{C}<->\mathrm{T}=1.91367, \mathrm{G}<->\mathrm{T}=1.00000$. The nucleotide frequency parameters were $f(A)=0.29792, f(C)=0.15023, f(G)=0.13726, f(T)=$ 0.41459 , and the gamma distribution parameter was 1.189 . In order to check a potential effect of the initial tree, the ML analysis was repeated with an initial tree produced by a distance-based method (using the BIONJ algorithm proposed by the PHYML software) and a similar result was obtained. The topology of the final ML tree is consistent with the results obtained by Fior and Karis (2007). Node robustness was assessed using the approximate likelihood ratio test (aLRT, Anisimova and Gascuel 2006) provided with the PHYML software program. We also performed a bootstrap procedure, based on a maximum parsimony heuristic search in PAUP* 4.0 
$(5,000$ replicates, start $=$ stepwise, addseq $=$ random, nreps $=1$, randomize $=$ addseq, swap $=$ tbr, multrees $=$ yes). The ML tree was edited in the MEGA4 program.

\section{Results}

\section{Differentiation of Arenaria Species in the Environmental Space}

The first two axes of the OMI analysis accounted for $82 \%$ of the floristic variance (Fig. 2a). All the explanatory variables were significantly correlated with at least one of the two OMI axes (Table 1). The first OMI axis (Fig. 2a) was highly significantly correlated with altitude (Pearson test, $r=0.85^{* * *}$ ), the first climatic PCA axis
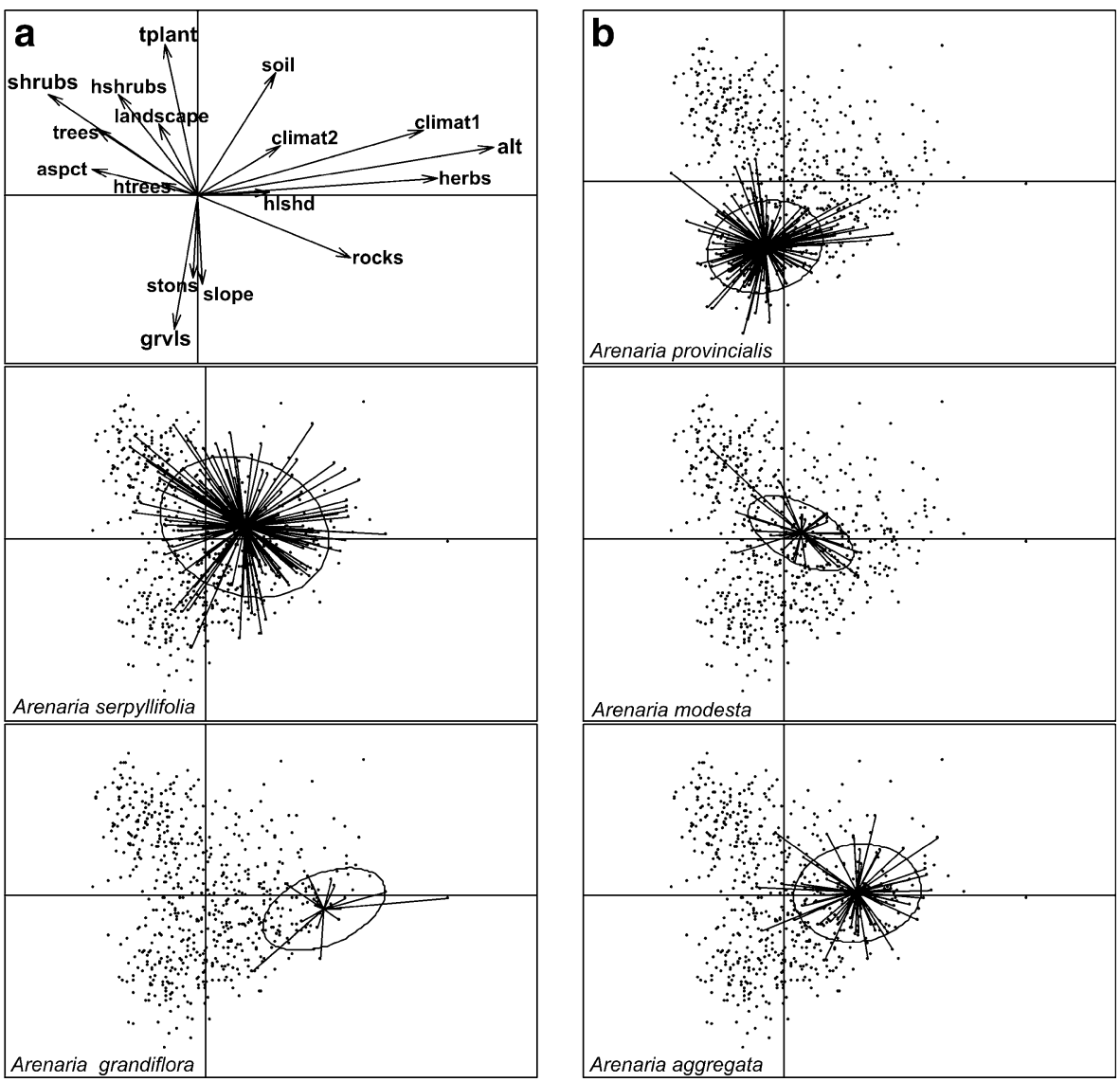

Fig. 2 Results of the OMI analysis of the Arenaria species in southern Provence. (a) canonical weight of the 17 environmental variables; see Electronic Supplementary Material 1 for a key to the abbreviations of the environmental variables. (b) diagram of the 624 sample locations (represented by dots) along the first two axes of the OMI analysis. The ellipses stand for outlying niches belonging to each of the five Arenaria species. Ellipses account for $67 \%$ of the variation in each Arenaria species. They are centred on the mean ordination scores; their widths and heights give the variance and their slopes give the covariance of the ordination scores 
Table 1 Pearson's correlation coefficients between the environmental variables and the first two axes of the OMI analysis

\begin{tabular}{|c|c|c|c|}
\hline Environmental variables & Code & OMI axis 1 & OMI axis 2 \\
\hline altitude (m) & alt & $0.85 * * *$ & $0.11 * *$ \\
\hline aspect & aspct & $-0.36^{* * *}$ & $0.12^{* *}$ \\
\hline bare rocks & rocks & $0.55^{* * *}$ & $-0.33 * * *$ \\
\hline bare stones & stons & $0.08^{*}$ & $-0.47 * * *$ \\
\hline bare gravel & grvls & $0.01 \mathrm{~ns}$ & $-0.76 * * *$ \\
\hline bare soil & soil & $0.21 * * *$ & $0.62 * * *$ \\
\hline total plant cover & tplant & $-0.24 * * *$ & $0.88 * * *$ \\
\hline high tree cover & htrees & $-0.16^{* * *}$ & $0.13 * *$ \\
\hline tree cover & trees & $-0.4 * * *$ & $0.47 * * *$ \\
\hline high shrub cover & hshrubs & $-0.33 * * *$ & $0.61 * * *$ \\
\hline shrub cover & shrubs & $-0.53 * * *$ & $0.58 * * *$ \\
\hline herbaceous plant cover & herbs & $0.72 * * *$ & 0.02 n.s. \\
\hline hillshade & hlshd & $0.23 * * *$ & 0.03 n.s. \\
\hline slope $(\%)$ & slope & 0.07 n.s. & $-0.46^{* * *}$ \\
\hline landscape plant cover & landscape & $-0.16^{* * *}$ & $0.39 * * *$ \\
\hline climate axis 1 & climat 1 & $0.72 * * *$ & $0.1 * * *$ \\
\hline climate axis 2 & climat2 & $0.15 * * *$ & $0.12^{* *}$ \\
\hline
\end{tabular}

*** $-P<0.001 ; * *-P<0.01 ; *-P<0.05$; n.s. - non significant.

$(r=0.72 * * *)$, herbaceous plant cover $(r=0.72 * * *)$, and shrub plant cover $(r=-0.53 * * *)$ (Table 1). The second OMI axis (Fig. 2a) was mainly correlated with the total plant cover $\left(r=0.88^{* * *}\right)$, bare soil $(r=0.62 * * *)$, gravel $\left(r=-0.76^{* * *}\right)$, stone $(r=-0.47 * * *)$ and slope $\left(r=-0.46^{* * *}\right)$ (Table 1). Locations with Arenaria species are mostly situated in open habitats (low tree and shrub cover) with high gravel and rock cover. Locations without Arenaria mainly occur in habitats with high plant cover and high tree and shrub cover (upper left corner of diagram). The Arenaria species all have some similar limiting environmental factors in common. However, some inter-species differences in the marginality index and niche breadth exist (Fig. 3, and Table 2).

The main results of the OMI analysis show that $i$ ) the realized niche of $A$. provincialis is clearly differentiated from other Arenaria niches (Figs. 2b and 3 ) and ii) this species grows under various conditions, as indicated by its distribution in the environmental space defined on axes 1 and 2 (Figs. 2, 3). This species is the only Arenaria taxon in southern Provence that colonizes scree slopes (negative values of OMI axis 2), while also growing both at very low altitudes (less than $10 \mathrm{~m}$ a.s.1.) near the sea (50 meters from the coastline) and at high altitudes up to the crests of summits (above 1,000 m a.s.1).

Arenaria serpyllifolia shows a wider ecological range than its congeners in southern Provence, because it has the greatest niche breadth (Table 2 and Fig. 3). In addition, A. serpyllifolia is the only taxon detected in the presence of other Arenaria species within the $100-\mathrm{m}^{2}$ floristic sampling areas. The realized niche of Arenaria modesta appears to be embedded in the niche of $A$. serpyllifolia, but has a smaller 
Fig. 3 Species niche position and niche breadth of Arenaria in southern Provence on the first two OMI axes. The horizontal bars correspond to the niche breadth of each species. Small vertical bars at the bottom of each panel correspond to the positions of sites along the axes

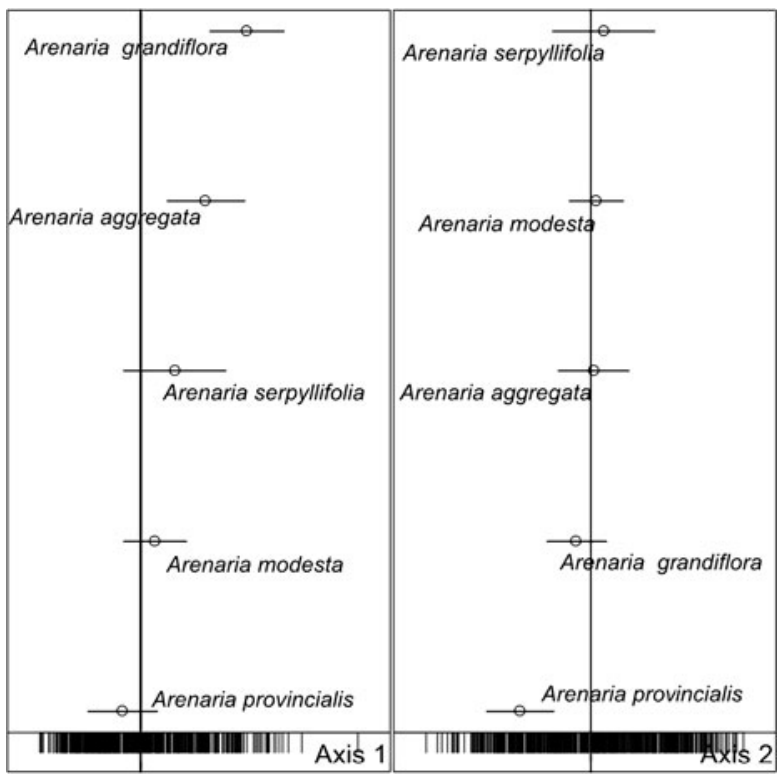

niche breadth (Table 2). This species is widely distributed over the study area, but it occurs only on dolomitic sandy soils, in small open patches surrounded by mattoral vegetation. Lastly, A. grandiflora and A. aggregata are marginal species in southern Provence (Table 2), i.e., A. aggregata grows in open rocky areas, but only on the summit crests of low mountain ranges above $400 \mathrm{~m}$ a.s.l., and A. grandiflora occurs only on summit crests and in cliff habitats above $900 \mathrm{~m}$ a.s.l. The latter species obtained the highest marginality score, as shown in Table 2.

\section{Niche Breadth and Regional Occupancy}

Niche breadth and regional occupancy were found to be broadly correlated $(r=0.61 * * *$, R Pearson, $N=32$ taxa, Table 2). Arenaria serpyllifolia and A. aggregata, which have wide niche breadths, both show high regional occupancies, while $A$. provincialis, $A$. modesta and $A$. grandiflora, which have smaller niche breadths, both show lower regional occupancies. Most species belonging to genera other than Arenaria that cooccur with $A$. provincialis (Table 2) are common species in southern Provence. They grow in herbaceous and fruticose habitats with high gravel and rock cover and along a wide altitudinal gradient (from 50 to above $1,000 \mathrm{~m}$ a.s.l.). The mean regional occupancy of these species is rated 40 and niche breadth is 6. By comparison, $A$. provincialis shows a lower regional occupancy (21) but a similar niche breadth (6.3). This result means that $A$. provincialis is absent from some of the suitable habitats within its distribution area.

\section{Comparison of Diaspore Traits}

Pairwise Kruskal-Wallis comparisons between the Arenaria species' seed traits were consistently significant $(P<0.001)$. In comparison with the small, light seeds of its 
Table 2 Niche parameters of Arenaria species and species associated with $A$. provincialis in southern Provence

\begin{tabular}{|c|c|c|c|c|}
\hline Taxa & $\begin{array}{l}\text { Marginality } \\
\text { index }\end{array}$ & $\begin{array}{l}\text { Niche } \\
\text { breadth }\end{array}$ & $\begin{array}{l}\text { Regional } \\
\text { occupancy }\end{array}$ & $\begin{array}{l}\text { Biogeographical } \\
\text { distribution }\end{array}$ \\
\hline Arenaria provincialis Chater \& G. Halliday & 29.1 & 6.3 & 21 & Endem. Prov. \\
\hline Arenaria aggregata (L.) Loisel. & 31.2 & 10.4 & 25 & NW Med. Mont. \\
\hline Arenaria serpyllifolia $\mathrm{L}$. & 8.8 & 13.7 & 52 & sub-Cosmopolite \\
\hline Arenaria modesta Dufour & 15.6 & 6.7 & 17 & W Med. Mont. \\
\hline Arenaria grandiflora L. & 54.7 & 7.6 & 10 & Euri-Med. \\
\hline Antirrhinum latifolium Mill. & 33.9 & 2.0 & 10 & NW Steno-Med. \\
\hline Amelanchier ovalis Medik. & 6.5 & 13.4 & 61 & Med. Mont. \\
\hline Asparagus acutifolius L. & 10.9 & 12.6 & 41 & Steno-Med. \\
\hline Biscutella valentina $\mathrm{L}$. & 8.7 & 8.8 & 35 & NW Med. \\
\hline Brachypodium retusum (Pers.) P.Beauv. & 1.8 & 11.4 & 59 & W Steno-Med. \\
\hline Centranthus ruber (L.) DC. & 15.2 & 10.4 & 35 & Steno-Med. \\
\hline Crucianella latifolia $\mathrm{L}$. & 12.9 & 12.9 & 32 & Steno-Med. \\
\hline Euphorbia characias L. & 4.0 & 10.0 & 43 & Steno-Med. \\
\hline Galium corrudifolium Vill. & 2.5 & 15.3 & 63 & Euri-Med. \\
\hline Geranium robertianum L. & 9.5 & 12.3 & 44 & Euri-Med. \\
\hline Globularia alypum L. & 10.4 & 10.4 & 24 & Steno-Med. \\
\hline Helichrysum stoechas (L.) Moench & 1.3 & 6.8 & 47 & W Steno-Med. \\
\hline Lactuca perennis L. & 10.2 & 8.6 & 46 & N Euri-Med. \\
\hline Laserpitium gallicum $\mathrm{L}$. & 14.1 & 11.8 & 36 & NW Med. Mont. \\
\hline Linaria supina (L.) Chaz. & 16.0 & 6.8 & 35 & sub-Atlantic \\
\hline Melica minuta L. & 18.1 & 8.7 & 32 & Steno-Med. \\
\hline Pimpinella tragium Vill. & 24.6 & 3.4 & 8 & Med.-Turan. \\
\hline Ptychotis saxifraga (L.) Loret \& Barrandon & 27.9 & 4.6 & 15 & SW Europe \\
\hline Quercus coccifera L. & 5.2 & 15.2 & 43 & W Steno-Med. \\
\hline Rhus coriaria L. & 10.0 & 12.5 & 31 & Steno-Med. \\
\hline Rosmarinus officinalis L. & 2.5 & 16.2 & 62 & Steno-Med. \\
\hline Rubia peregrina L. & 6.5 & 10.4 & 45 & Steno-Med. \\
\hline Sedum sediforme (Jacq.) Pau & 6.0 & 11.1 & 55 & Steno-Med. \\
\hline Senecio cineraria DC. & 16.0 & 8.5 & 11 & W Med. \\
\hline Smilax aspera L. & 9.3 & 5.2 & 54 & Paleo-sub-Tropical \\
\hline Staehelina dubia L. & 4.1 & 7.9 & 41 & W Med. \\
\hline Thymus vulgaris L. & 1.8 & 12.3 & 71 & W Steno-Med. \\
\hline
\end{tabular}

Marginality index - distance between the mean habitat conditions used by a species and the mean habitat conditions across the whole study area; Niche breadth - the range of each species in the environmental space; Regional occupancy - number of occupied grid cells $(5 \times 5 \mathrm{~km})$ at which each plant species was recorded in southern Provence; Biogeographical distribution sensu Pignatti (1982) (Endem. Prov. Provençal endemic; Med. Mont. - Mediterranean mountains; Euri-Med. - Mediterranean sensu lato; Steno-Med. - Mediterranean sensu stricto; Med.-Turan. - Mediterranean Turanean). The species most frequently cohabiting with A. provincialis were determined based on the literature (Molinier 1934; Loisel 1976; Baumel et al. 2009) and our own data. 
Table 3 Diaspore traits compared between Arenaria species in the NW Mediterranean region

\begin{tabular}{llllll}
\hline Taxon & Life cycle & Diaspore & $\begin{array}{l}\text { Diaspore } \\
\text { mass (g) }\end{array}$ & $\begin{array}{l}\text { Seeds per } \\
\text { capsule }\end{array}$ & $\begin{array}{l}\text { Seed sets per } \\
\text { individual }\end{array}$ \\
\hline Arenaria provincialis & annual & capsule & 1.62 & $1.06(1-2)$ & $106(25-486)$ \\
Arenaria aggregata & perennial & seed & 0.48 & $5.1(3-9)$ & $1587(370-3546)$ \\
Arenaria ciliata & perennial & seed & 0.18 & - & - \\
Arenaria cinerea & biennial/perennial & seed & 0.33 & $11.6(7-20)$ & $431(60-175)$ \\
Arenaria grandiflora & perennial & seed & 0.61 & $4.4(3-9)$ & $976(110-3137)$ \\
Arenaria hispida & perennial & seed & 0.14 & - & - \\
Arenaria modesta & annual & seed & 0.07 & $16.02(7-25)$ & $252(35-1749)$ \\
Arenaria nevadensis & annual & seed & $0.14 *$ & - & - \\
Arenaria serpyllifolia & annual & seed & 0.07 & $11.1(5-17)$ & $350(66-1269)$ \\
\hline
\end{tabular}

Diaspore mass - weight per 1,000 units; - - not calculated; * - seed mass based on Lorite et al. (2007). Means and the minimum and maximum number of seeds per capsule and seed sets per individual (in brackets).

congeners, the seeds of $A$. provincialis were much larger and heavier (Table 3 ). Except for $A$. provincialis $(1,000$ seeds mass $=1.081 \mathrm{~g})$, the values obtained on the other eight species ranged from $0.07 \mathrm{~g}$ to $0.48 \mathrm{~g}$ (mass of 1,000 seeds). As shown in Table 3, the median mass of 1,000 seeds was found to be $0.18 \mathrm{~g}$, whereas the seeds of the following four species are well above this limit: $A$. provincialis, $A$. cinerea, $A$. aggregata and $A$. grandiflora. The seeds of $A$. serpyllifolia and $A$. modesta are the lightest and the seed of $A$. ciliata, $A$. hispida and $A$. nevadensis are near the median value. Considerable differences in seed production were observed between the mother plants of all these species, and A. provincialis showed a lower mean seed production than any of its congeners (Table 3 ). In addition, an unusual process of dispersal occurs in A. provincialis because its diaspore corresponds to the capsule, not the seed. Indeed, the ovoid capsule containing one or very occasionally two seeds remains closed and falls from the plant at maturity. The mass of 1,000 capsules of $A$. provincialis is $1.62 \mathrm{~g}$. It was observed on the field that the capsules of the seven other species are always attached to the calyx and that they are always open when mature. During several field trips to populations of $A$. provincialis, it was observed that the mature capsules disperse very quickly from the plant, making a small jump corresponding to an unknown ejection process from the calyx. After being released, the ejected fruit landed quite near the mother: the dispersal never went beyond one meter from the plant. It was observed on several occasions that capsules of $A$. provincialis rebounded between rocky particles and sunk quickly into the first rocky layer of the soil. By contrast, the small seeds of $A$. serpyllifolia fell to the ground from open capsules and remained on the surface of the soil for some time after their dispersal.

\section{Phylogenetic Position of Arenaria provincialis}

The matK gene ML tree showed that the Arenaria genus can be subdivided into two main clearly identifiable clades, and that it is closely related to the Moehringia genus 


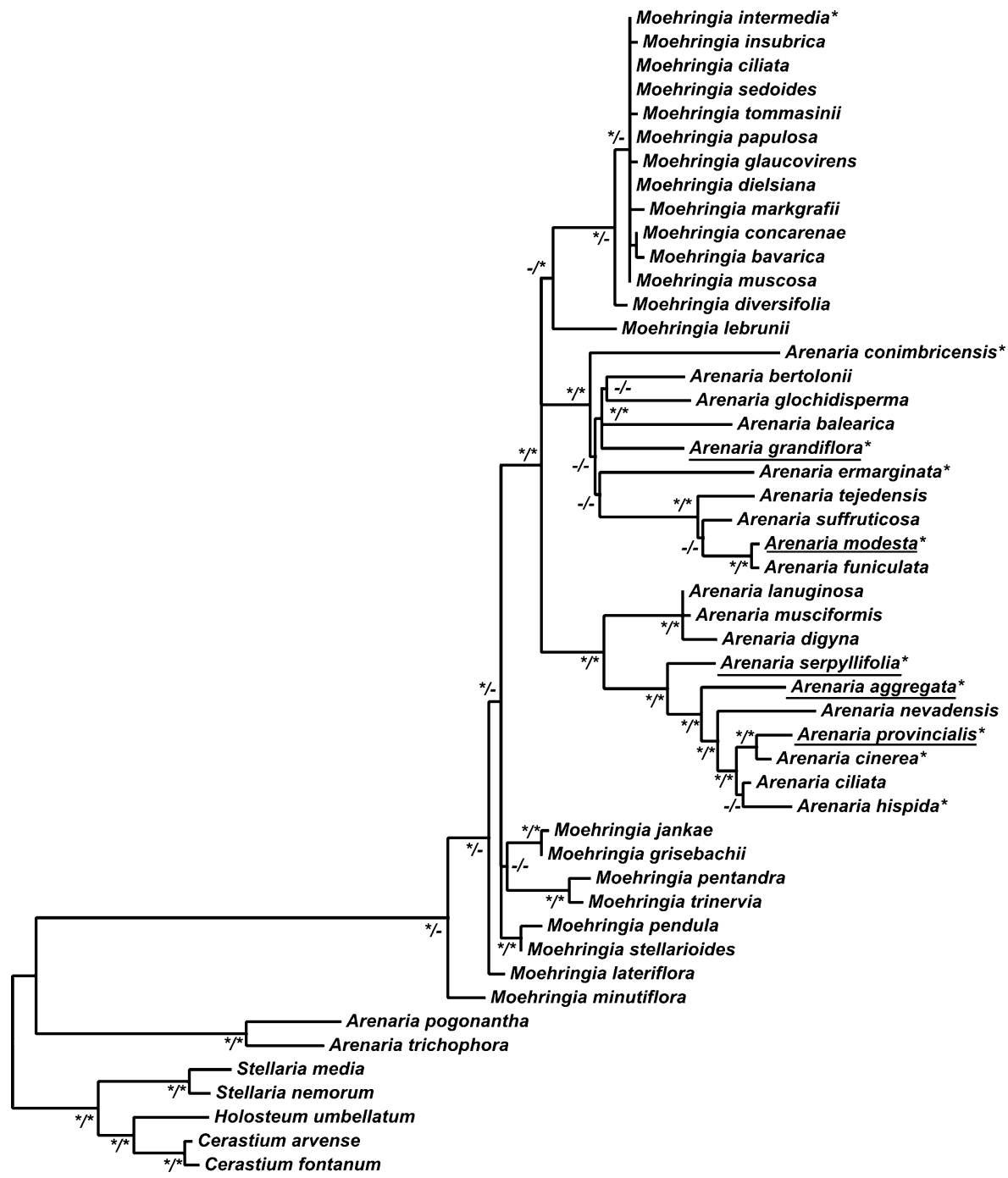

Fig. 4 Phylogenetic tree optimized by performing a maximum likelihood analysis with the PHYML software program, using the matK gene. Node support is indicated by aLRT/bootstrap tests, $*->75 \%,--\leq 75 \%$. Newly sequenced taxa are labelled with an asterisk *. Taxa included in the present comparative study are underlined

(Fig. 4). The general structure of this tree is similar to that of the matK tree obtained by Fior and Karris (2007).

The Arenaria species from southern Provence belong to the two main clades found to exist in this genus, and the taxa most closely related to A. provincialis are A. aggregata, followed by $A$. serpyllifolia. However, trustworthy bootstrap and aLRT tests have shown that $A$. provincialis and $A$. cinerea are closely connected and form a clade along with $A$. ciliata and $A$. hispida. Arenaria nevadensis occupies an intermediate position between this clade and A. aggregata. It therefore emerged that the species most closely related to $A$. provincialis, based on the ML tree, are not 
present in southern Provence. Based on the present data, the four closest relatives of A. provincialis inhabit highland areas, and three of them are also narrow endemics: A. nevadensis grows only in small high altitude locations in the Sierra Nevada (Spain), A. hispida, a local endemic occurring in the south of France, is encountered mostly on dolomitic highlands such as the Causses plateaus, and A. cinerea is a narrow endemic occurring mainly around the Verdon canyon (in the southern French Alps). By contrast, $A$. ciliata is widely distributed over the Alps, as well as occurring at higher altitudes of more than 1,000 $\mathrm{m}$ a.s.1.. The divergences in the matK sequences observed between $A$. provincialis and its four closest relatives amount to $0.93 \% \quad(A$. provincialis - A. cinerea), 1.40\% (A. provincialis - A. ciliata), 2.18\% (A. provincialis - A. hispida), and 3.11\% (A. provincialis - A. nevadensis).

\section{Discussion}

It has long been recognized that rare species can differ from their more common relatives in terms of several biological traits (Kunin and Gaston 1997). Three noteworthy results emerge from the comparisons conducted in the present study. First, the results of the OMI analysis clearly show that $A$. provincialis has a strongly differentiated realized niche. Secondly, in terms of the dispersal of the fruits and seeds, the endemic A. provincialis has a very different type of diaspore from that of other Arenaria species. And thirdly, the phylogenetic ML tree drawn up here confirms that A. provincialis belongs to a monophyletic group containing A. serpyllifolia, which is the type species of Arenaria genus. The closest phylogenetic relatives of $A$. provincialis are not sympatric in southern Provence (Fig. 4), but our current phylogenetic knowledge about Arenaria suggests that these species inhabit highland areas in neighbouring (Verdon) and more distant mountains (Alps and Causses).

\section{Realized Niche, Regional Occupancy and Global Range Size}

The present findings are in agreement with those of previous studies on the usual traits of endemic Mediterranean plant species, showing that they tend to occur in steep, open, rocky habitats, and colonize harsh habitats with low rates of competition and disturbance (Médail and Verlaque 1997; Lavergne et al. 2004; Thompson 2005; Domínguez Lozano and Schwartz 2005; Casazza et al. 2005). The Arenaria species studied here show some ecological similarities, i.e., they all occur in open rocky areas with a sparse vegetation cover, like most other Arenaria and the Moehringia taxa. Despite these similarities, the various Arenaria taxa are rarely found growing together in southern Provence. It was established here that the realized niches are quite different, in terms of the two main gradients involved in open areas, namely the altitudinal (OMI axis 1) and vegetation cover (OMI axis 2) gradients, the latter of which depend on the granulometry of the soil and the steepness of the slope (Table 1, axis 2, see the scores attributed to the variables: total plant cover, slope rate, bare soil, bare gravel, etc.).

The widespread species $A$. serpyllifolia has a low level of marginality and occupies a broad niche partly or completely overlapping those of all the other Arenaria species; whereas A. aggregata and A. grandiflora are characterized by a more marginal, narrower niche (Fig. 2, Table 2); in southern Provence, these two 
perennial species inhabit highlands and rocky habitats such as cliffs and summits. Among the Arenaria taxa compared here, A. grandiflora obtained the highest marginality scores and the smallest regional occupancy rates because its occurrences are restricted to only a small part of the focus area (19 sampled locations), where the plant communities are similar. The most surprising characteristic of $A$. grandiflora is that it has a wide range but a fragmented pattern of distribution restricted to several mountains in Europe and north Africa (Sáez et al. 2002), and it occurs very rarely in lowland areas (Bottin et al. 2007). Arenaria modesta is an interesting case because this species is known to be rare in the present study area. Several field trips were necessary to considerably update its pattern of distribution: its regional rate of occupancy is therefore not very high, without being the lowest recorded in this study. However, this species was found to have a rather low marginality score, which it is difficult to explain. Contrary to A. aggregata and A. grandiflora, which occur only in rocky highland habitats, $A$. modesta is restricted to very small patches of sandy dolomitic soil occurring in a wider range of altitudes and shrub covers, which were the variables showing the greatest inertia on axis 1 in the OMI analysis.

In comparison with the four other Arenaria species present in the focus study area, A. provincialis occupies a specialized niche, because as can be seen from Fig. 2, it is the only species in which the niche center occupies an environmental space corresponding to scree slopes (bottom left in Fig. 2, and Table 1). Although it is the only Arenaria species able to colonize scree slopes, it also occurs frequently on other rocky habitats and grows in a wide range of altitudes, from dry sea level sites to mountain summit habitats $(>1,000 \mathrm{~m}$ a.s.1.). It therefore occupies a larger environmental space than some rocky habitat specialists such as $A$. aggregata and $A$. grandiflora (Fig. 2). In view of the position of the centre of its niche shown in Fig. 2, it can hypothesized that the optimum conditions for $A$. provincialis may exist on scree slopes, on soil with a high gravel content and at altitudes below $400 \mathrm{~m}$ a.s.l. Habitats of the latter kind occur very commonly in the "Calanques" area, where $A$. provincialis is abundant. But this hypothesis needs to be tested by monitoring the population dynamics, because realized niches can be very different from the fundamental niches (Pulliam 2000).

Species having similar niche breadths and habitat requirements to those of $A$. provincialis (see Results) can still have much larger regional occupancies, and this is obviously also the case at biogeographical level (Table 2). Therefore, despite its ability to colonize various rocky habitats (axis 2 in Fig. 2) along an altitudinal range of approximately one thousand meters (axis 1 in Fig. 2), A. provincialis still has a smaller geographical range than ecologically similar and co-occurring species within its distribution area. This can be seen on the western and eastern edges of its range of distribution, where it is absent from many rocky open places and scree slopes harbouring these species. Analyzing the niche alone therefore cannot explain some of the limits of the biogeographical distribution of $A$. provincialis.

\section{Diaspore Traits: A Heavy Diaspore for Arenaria provincialis}

In previous studies, diaspore traits were found to be significantly correlated with dispersal ability (Andersen 1992; Fenner and Thompson 2005), and dispersal ability has often been correlated with species distribution (Oakwood et al. 1993; Rossetto 
and Kooyman 2005; Morin and Chuine 2006; Becker 2010). Lavergne et al. (2004) observed that endemic species produce fewer seeds per plant than their more widespread congeners, but these authors did not observe any consistent differences in seed mass. One of the main results obtained in the present study is that $A$. provincialis is characterized by a very different plant dispersal unit from those of its relatives. Contrary to all the phylogenetic relatives studied here, which have many very small, light seeds which are dispersed from open dry capsules, the diaspore of $A$. provincialis is an indehiscent ovoid capsule containing one or occasionally two large, heavy seeds (mass per 1,000 seeds $=1.081 \mathrm{~g}$, mass per 1,000 capsules $=1.62 \mathrm{~g}$ ). Based on what is known so far about the phylogeny of Arenaria, even its closest phylogenetic relatives, A. cinerea, A. hispida and A. ciliata, release smaller seeds from open dry capsules; the diaspore of $A$. provincialis can therefore be assumed to have resulted from a specific evolutionary pathway taken by this species.

When the capsules of $A$. provincialis are mature, they are released via an ejection process, fall directly onto the ground, rebound between rocky particles and sink into the topmost layers of soil. The distance covered by the initial dispersal process is less than one meter, and any secondary dispersal processes are likely to be infrequent because the capsules are trapped between small rocks and particles of gravel. This very limited dispersal capacity was confirmed by the results of a census carried out on 4- $\mathrm{m}^{2}$ areas, which showed that the positions occupied by individuals remained practically unchanged year after year, which is quite a surprising finding in view of the fact that $A$. provincialis has only a short annual life span (Baumel et al. 2009): it means that seedlings always take root close to the mother plants. Small dispersal distances are presumably more efficient in rocky habitats such as stone cracks and scree slopes, because they prevent diaspores from reaching unsuitable patches and make it possible for seeds to find free spaces between rocks and to reach down to lower layers of fine substrate. Another striking example of how dispersal processes have evolved has been reported in the case of the narrowly endemic Arenaria alfacarensis, which grows in rocky habitats between 100 and 200 ma.s.l. in the Baetic mountains (southern Spain): Goyder (1987) has reported that its capsules open only when they are wet and that its seeds are dispersed over short distances by water drops (via "splash" dispersal processes). Although dispersal by ants has been studied in the Moehringia genus (Casazza et al. 2008), very few studies have been published on seed dispersal processes in Arenaria species. The mode of dispersal occurring in A. serpyllifolia has been reported to be anemochory (Grime et al. 1988), but because the seeds of $A$. aggregata, A. grandiflora, A. cinerea and A. provincialis are much heavier (Table 3 ), they may be dispersed via a process of anemochory or barochory, depending on their exposure and the strength of the wind.

Apart from the special case of $A$. provincialis, considerable interspecies variations were observed here in the seed mass and the number of seeds per capsule. The present findings suggest that correlations may exist between habitat and seed traits (mass and size of seeds, number of seeds). As shown in Table 3, species having a seed mass above the median value (A. provincialis, A. cinerea, A. aggregata and A. grandiflora) inhabit dry and/or rocky habitats, whereas species having a lower seed mass occur under moister conditions and/or in deeper soils (A. ciliata, A. nevadensis, A. serpyllifolia) or sandy soils (A. modesta, A. hispida). Larger resources stored in the seeds of $A$. provincialis as well as those of $A$. aggregata, A. grandiflora, and A. cinerea 
probably help young seedlings to survive and to quickly develop roots in rocky habitats characterized by a shortage of nutrients, scarce fine soil, and low water supplies. In addition, the extreme compactness (cliffs) or mobility (screes) of some rocky substrates will prevent most of the plants from rooting and surviving (Minelli and Stoch 2006). In harsh habitats of this kind, the ability to quickly develop a deep root could be an advantage for species having large seeds and plenty of resources providing seedlings with their requirements. The hypothesis that a correlation may exist between the regeneration niche and the seed traits (Grubb 1977) in Arenaria needs to be tested in further comprehensive studies on seedling survival and root development.

Seed germination rates of $45 \%$ in the case of A. provincialis (Baumel et al. 2009 and unpubl. data) versus $76 \%$ in that of $A$. serpyllifolia (unpubl. data) were previously calculated. Large $A$. provincialis seed banks were found to exist in the soil, but a high rate of seed loss was also found to occur, possibly due to predation (unpubl. data). Given the dense populations of individuals existing on the finest scale (Baumel et al. 2009), the presence of a seed bank and the large number of seeds produced by each individual (Table 3 ), the rarity of $A$. provincialis does not seem to be attributable to the reproductive capacity of this species.

\section{Phylogenetic Data Support the Allopatric Speciation Hypothesis}

When the ranges of sister taxa do not overlap, an allopatric speciation process is often thought to be at work (Barraclough and Nee 2001; Graham et al. 2004). The differences observed between the patterns of distribution of $A$. provincialis, $A$. cinerea, A. hispida, A. ciliata and $A$. nevadensis are certainly consistent with the idea that allopatric speciation processes may well have occurred as the result of past isolation events. Because the closest phylogenetic relatives of $A$. provincialis, based on the current phylogenetic knowledge about Arenaria, inhabit upland areas, it is likely that $A$. provincialis may have emerged after the isolation of an ancestral population in a southern, lowland enclave, which subsequently became warmer and drier. When did this isolation event occur? The rocky habitats of A provincialis show signs (such as lapiaz and huge scree slopes) of the strong frost erosion processes known to have taken place during the cold stages of the Quaternary climatic oscillations. In a recent study, Valente et al. (2010) presented a phylogenetic and temporal framework for the evolution of Caryophyllaceae (see supplementary material in Valente et al. 2010). The latter authors drew up a time-calibrated phylogenetic tree based on matK sequences where the node between $A$. serpyllifolia and $A$. nevadensis was dated 9 million years ago (Mya). The position of $A$. provincialis in the phylogenetic tree and the corresponding branch length show that its origin occurred after the divergence of A. serpyllifolia and A. nevadensis. However, because there is some uncertainty about the divergence times (Valente et al. 2010) and there are very few Caryophyllaceae fossils available to improve calibration of phylogenetic trees, it is not currently possible to assign the origin of $A$. provincialis exactly to the late Tertiary or the Quaternary period.

Although $27 \%$ to $48 \%$ of the Mediterranean plant population consists of annual species, they occur 3 to 5 times less frequently in the local endemic flora of seven Mediterranean regions than in their flora as a whole (Verlaque et al. 1997). This situation may explain why only a few molecular studies (such as that by Tremetsberger et al. 
2005) have dealt with annual Mediterranean plants. The aridity of the climate, especially during the summer drought, has important effects on speciation processes (Stebbins and Major 1965), by promoting short-lived species avoiding the climatic stress of the summer drought (Venable and Lawlor 1980; Madon and Médail 1997). A recent comparative phylogenetic study has shown that summer heat and increasing winter aridity may be important factors promoting the transition from a perennial to annual life cycle in the genus Oenothera in a desert environment (Evans et al. 2005). The authors of a phylogenetic analysis of daisies (Asteraceae) have described the possible existence of three independent origins of the annual life forms which have developed from perennials during the establishment of summer drought in the Mediterranean climate (Fiz et al. 2002). In the current phylogenetic tree of Arenaria, the annual life forms are mixed with perennial life forms, which is consistent with the possibility that independent changes in the life span may have occurred. Our own results suggest that $A$. provincialis may have evolved an annual life span in response to the Mediterranean climate because their closest phylogenetic relatives $A$. cinerea, $A$. hispida, and A. ciliata are perennials. However, the data obtained here on Arenaria are not very clear-cut in this respect because an exhaustive sampling of Arenaria species will be necessary to guarantee that sister-species relationships are well established.

\section{New Insights into the Systematics of Arenaria provincialis}

After being discovered in the early nineteenth century by Robillard and Castagne "dans des endroits rocailleux qui entourent Marseille" (in rocky places around Marseille), A. provincialis was initially named Gouffeia arenarioides DC. or «Gouffeia fausse Sabline» (de Candolle 1815) because the flower has two carpels instead of the usual three present in the Arenaria genus. Our phylogenetic data support the idea that A. provincialis is definitely a member of the Arenaria genus, and do not support its classification within the genus Gouffeia. The ovary with two styles, the indehiscent capsule, the large seeds and the specific diaspore of $A$. provincialis are therefore autapomorphic traits. Alignment and phylogenetic analysis of the ribosomal internal spacer sequences (ITS 1 and ITS 2) are also in keeping with this conclusion (Genbank accession number DQ810289, analysis not shown). McNeill (1962) himself observed that $A$. provincialis "in most respects resembles Arenaria subgenus Arenaria, of which it is probably a bicarpellary derivative". Although our samples of Arenaria taxa were not sufficiently exhaustive to solve the problem of the sister species of $A$. provincialis, the low sequence divergence observed between $A$. provincialis and $A$. cinerea, along with the rather short geographical distance between their patterns of distribution, support the hypothesis that there exist very close phylogenetic relationships between the two species. However, the two species differ in several respects, because A. cinerea is a biennial or perennial species with a more robust vegetative form possessing a tristylous flower and an open capsule, which inhabits dry, rocky grasslands but not scree slopes. Among the closest relatives of A. provincialis, A. ciliata is a highly polymorphic mountain species known to be a complex consisting of several infraspecific taxa inhabiting European mountain systems and northern Europe (Wyse Jackson and Parnell 1987). Only comprehensive studies of the morphological, cytological and molecular polymorphism of the genus Arenaria will improve its 
systematics. In this line, only the section Arenaria sect. Plinthine (A. aggregata being its type) has been thoroughly studied so far (Valcárcel et al. 2006), and found to carry a very weak phylogenetic signal, which was taken to reflect the occurrence of reticulate evolution and genome-wide processes such as polyploidy.

\section{Conclusion}

Although its niche tends to involve rocky, harsh, azonal habitats, A. provincialis cannot be said to be a steno-endemic species because it occurs in various plant communities along an altitudinal gradient of nearly 1,000 meters. The present field studies and comparisons based on multivariate niche analyses have shown that $A$. provincialis is absent from several suitable places within its range distribution. Because there are no obvious physical barriers or ecological factors preventing this species from colonizing these places, it was concluded that niche breadth alone does not suffice to explain the endemism of A. provincialis. Comparisons between the fruit and seed traits of various Arenaria species showed that A. provincialis have evolved an unusually large diaspore, which may have prevented it from extending its geographical range. This large diaspore may have constituted a means of surviving on the steep scree slopes caused by past changes in environment and the regeneration niche (sensu Grubb 1977) of the ancestor of A. provincialis. Lastly, the results of our phylogenetic analysis suggest that this evolution may have occurred during or after a past isolation event occurring in a southern lowland enclave. Therefore, the isolation of its ancestor in southern Provence may have been a decisive historical factor contributing to the endemism of this species.

Acknowledgements We thank the Conservatoire Botanique National Méditerranéen de Porquerolles for providing unpublished data about Arenaria taxa locations and allowing us to collect Arenaria. We thank Franck Torre and Stéphane Dray for discussions and comments about our results. We thank Daniel Montesinos for providing samples of Arenaria conimbricensis from Spain. We thank Jessica Blanc for greatly improving the English in this paper and three anonymous reviewers for their helpful comments. This research was supported by the CNRS, the French National Office of Forests (ONF) and the General council of Bouches du Rhône district (CG13).

\section{References}

Andersen MC (1992) An analysis of variability in seed settling velocities of several wind-dispersed Asteraceae. Amer J Bot 79:1087-1091

Anisimova M, Gascuel O (2006) Approximate likelihood ratio test for branches: a fast, accurate and powerful alternative. Syst Biol 55:539-552

Barbero M, Bonin G, Loisel R, Quézel P (1990) Changes and disturbances of forest ecosystems caused by human activities in the western part of the Mediterranean basin. Vegetatio 87:151-173

Barraclough TG, Nee S (2001) Phylogenetics and speciation. Trends Ecol Evol 16:391-399

Baskin JM, Snyder KM, Walck JL, Baskin CC (1997) The comparative autecology of endemic, globallyrare and geographically-widespread, common plant species: Three case studies. Southwest Naturalist 42:384-399

Baumel A, Affre L, Véla E, Auda P, Torre F, Youssef S, Tatoni T (2009) Ecological magnitude and fine scale dynamics of the Mediterranean narrow endemic therophyte, Arenaria provincialis (Caryophyllaceae). Acta Bot Gallica 156:259-272 
Becker T (2010) Explaining rarity of the dry grassland perennial Astragalus exscapus. Folia Geobot 45:303-321

Bottin L, Quilichini A, Bardin P, Moret J, Machon N (2007) Re-establishment trials in endangered plants: A review and the example of Arenaria grandiflora, a species on the brink of extinction in the Parisian region (France). Ecoscience 14:410-419

Brown JH (1984) On the relationship between abundance and distribution of species. Amer Naturalist $124: 255-279$

Brown JH, Stevens GC (1996) The geographic range: Size, shape, boundaries, and internal structure. Annual Rev Ecol Syst 27:597-623

Calenge C, Basille M (2008) A general framework for the statistical exploration of the ecological niche. $J$ Theor Biol 252:674-685

Casazza G, Barberis G, Minuto L (2005) Ecological characteristics and rarity of endemic plants of the Italian Maritime Alpes. Biol Conservation 123:361-371

Casazza G, Borghesi B, Roccotiello E, Minuto L (2008) Dispersal mechanisms in some representatives of the genus Moehringia L. (Garyophyllaceae). Acta Oecol 33:246-252

Chater AO, Halliday G (1964) Arenaria L. In Tutin TG, Heywood VH, Burges NA, Valentine DH, Walters SM Webb DA (eds) Flora Europaea 1. Cambridge University Press, Cambridge, pp 140-148

Choler P, Michalet R (2002) Niche differentiation and distribution of Carex curvula along a bioclimatic gradient in the south western Alps. J Veg Sci 13:851-858

Chown SL (1997) Speciation and rarity: separating cause from consequence. In Kunin WE, Gaston KJ (eds) The biology of rarity. Chapman \& Hall, London, pp 91-109

Cornelissen JH, Lavorel CS, Garnier E, Diaz S, Buchmann N, Gurvich DE, Reich PB, ter Steege H, Morgan HD, van der Heijden MGA, Pausas JG, Poorter H (2003) A handbook of protocols for standardised and easy measurement of plant functional traits worldwide. Austral J Bot 51:335-380

Crouzet A (1966) Sur les adaptations morphologiques et anatomiques de Gouffeia arenarioides. Bull Mus Hist Nat (Marseille) 26:141-159

Crouzet N, Pavon D, Michaud H (2009) Mise à jour de la liste des plantes vasculaires du département des Bouches-du-Rhône. Bull Soc Linn Provence 60:55-73

Cruon R (2008) Le Var et sa flore. Plantes rares ou protégées. Naturalia Publications, Turriers

Debussche M, Thompson JD (2003) Habitat differentiation between two closely related Mediterranean plant species, the endemic Cyclamen balearicum and the widespread C. repandum. Acta Oecol 24:35-45

de Candolle AP (1815) Flore française, ou descriptions succinctes de toutes les plantes qui croissent naturellement en France, disposées selon une nouvelle méthode d'analyse, et précédées par un Exposé des Principes élémentaires de la Botanique. Desray Librairie, Paris

Dolédec S, Chessel D, Gimaret-Carpentier C (2000) Niche separation in community analysis: A new method. Ecology 81:2914-2927

Domínguez Lozano F, Schwartz MW (2005) Comparative taxonomic structure of the floras of two Mediterranean-climate regions: Iberia and California. Diversity Distrib 11:399-408

Doyle JJ, Doyle JL (1987) A rapid DNA isolation procedure for small quantities of fresh leaf tissue. Phytochem Bull 19:11-15

Dumas E, Jappiot M, Tatoni T (2008) Mediterranean urban-forest interface classification (MUFFIC): A quantitative method combining SPOT5 imagery and landscape ecology indices. Landscape Urban Planning 84:183-190

Evans MEK, Hearn DJ, Hahn WJ, Spangle JM, Venable DL (2005) Climate and life history in evening primroses (Oenothera, Onagraceae): a phylogenetic comparative analysis. Evolution 59:1914-1927

Fenner M, Thompson K (2005) The ecology of seeds. Cambridge University Press, Cambridge

Fior S, Karis PO (2007) Phylogeny, evolution and systematics of Moehringia (Caryophyllaceae) as inferred from molecular and morphological data: a case of homology reassesment. Cladistics 23:362-372

Fior S, Karis PO, Casazza G, Minuto L, Sala F (2006) Molecular phylogeny of the Caryophyllaceae (Caryophyllales) inferred from chloroplast matK and nuclear rDNA ITS sequences. Amer $J$ Bot 93:399-411

Fiz O, Valcárcel V, Vargas P (2002) Phylogenetic position of Mediterranean Astereae and character evolution of daisies (Bellis, Asteraceae) inferred from nrDNA ITS sequences. Molec Phylogenet Evol 25:157-171

Gachet S, Véla E, Tatoni T (2005) BASECO: a floristic and ecological database of Mediterranean French flora. Biodivers \& Conservation 14:1023-1034

Gaston KJ (1994) Rarity. Chapman \& Hall, London

Gitzendanner MA, Soltis PS (2000) Patterns of genetic variation in rare and widespread plant congeners. Amer J Bot 87:783-792 
Goyder DJ (1987) Observations on the geographical distribution, reproductive biology and ecology of Arenaria alfacarensis Pamp. Anales Jard Bot Madrid 44:285-297

Graham CH, Ron SR, Santos JC, Schneider CJ, Moritz C (2004) Integrating phylogenetics and environmental niche models to explore speciation mechanisms in dendrobatid frogs. Evolution 58:1781-1793

Grime JP, Hodgson JG, Hunt R (1988) Comparative plant ecology: a functional approach to common British species. Unwin-Hyman, London

Grubb PJ (1977) The maintenance of species-richness in plant communities: the importance of the regeneration niche. Biol Rev 52:107-145

Guindon S, Gascuel O (2003) A simple, fast, and accurate algorithm to estimate large phylogenies by maximum likelihood. Syst Biol 52:696-704

Hanski I, Kouki J, Halkka A (1993) Three explanations of the positive relationship between distribution and abundance of species. In Ricklefs RE, Schluter D (eds) Species diversity in ecological communities: historical and geographical perspectives. University of Chicago Press, Chicago, pp 108-116

Heino J, Soininen J (2006) Regional occupancy in unicellular eukaryotes: a reflection of niche breadth, habitat availability or size-related dispersal capacity? Freshwater Biol 51:672-685

Higgins DG, Bleasby AJ, Fuchs R (1992) Clustal V: Improved software for multiple sequence alignment. Computer Appl Biosci 8:189-191

Hijmans RJ, Guarino L, Cruz M, Rojas E (2001) Computer tools for spatial analysis of plant genetic resources data: 1. DIVA-GIS. Pl Genet Resources Newslett 127:15-19

Hijmans RJ, Cameron SE, Parra JL, Jones PG, Jarvis A (2005) Very high resolution interpolated climate surfaces for global land areas. Int J Climatol 25:1965-1978

Hutchinson GE (1957) Concluding remarks. Cold Spring Harbor Symp Quant Biol 22:415-427

Kunin WE, Gaston KJ (1997) The biology of rarity. Causes and consequences of rare-common differences. Chapman \& Hall, London

Lavergne S, Thompson JD, Garnier E, Debussche M (2004) The biology and ecology of narrow endemic and widespread plants: a comparative study of trait variation in 20 congeneric pairs. Oikos 107:505-518

Lesica P, Yurkewycz R, Crone EE (2006) Rare plants are common where you find them. Amer J Bot 93:454-459

Loisel R (1976) La végétation de l'étage méditerranéen dans le sud-est continental français. Thèse de Doctorat d'Etat, Université d'Aix-Marseille III, Marseille

López González G (1990) Arenaria L. In Castroviejo S, Laínz M, López González P, Montserrat P, Muñoz Garmendia F, Paiva J, Villar L (eds) Flora iberica 2. Real Jardín Botánico, Madrid, pp 172-224

Lorite J, Ruiz-Girela M, Castro J (2007) Patterns of seed germination in Mediterranean mountains: Study on 37 endemic or rare species from Sierra Nevada, SE Spain. Candollea 62:5-16

Madon O, Médail F (1997) The ecological significance of annuals on a Mediterranean grassland (Mt Ventoux, France). Pl Ecol 129:189-199

McNeill J (1962) Taxonomic studies on the Alsinoideae I. Generic and infra-generic groups. Notes Roy Bot Gard Edinburgh 24:79-155

Médail F, Verlaque R (1997) Ecological characteristics and rarity of endemic plants from southeast France and Corsica: Implications for biodiversity conservation. Biol Conservation 80:269-281

Minelli A, Stoch F (2006) Rocky slopes and screes. The hazard of a precarious life. Italian habitats 13. Museo Friulano di Storia Naturale, Udine

Molinier R (1934) Etudes phytosociologiques et écologiques en Provence occidentale. Ann Mus Hist Nat Marseille 27:1-274

Morin X, Chuine I (2006) Niche breadth, competitive strength and range size of tree species: a trade-off based framework to understand species distribution. Ecol Lett 9:185-195

Oakwood M, Jurado E, Leishman M, Westoby M (1993) Geographic ranges of plant species in relation to dispersal morphology, growth form and diaspore weight. J Biogeogr 20:563-572

Pignatti S (1982) Flora d'Italia 1. Edagricole, Bologna

Posada D, Crandall KA (1998) MODELTEST: testing the model of DNA substitution. Bioinformatics $14: 817-818$

Pulliam HR (2000) On the relationship between niche and distribution. Ecol Lett 3:349-361

Quézel P, Santa S (1962) Nouvelle flore de l'Algérie et des régions désertiques méridionales. CNRS, Paris

$\mathrm{R}$ development Core Team (2009) R: language and environment for statistical computing. $\mathrm{R}$ foundation for statistical computing, Vienna. Available at: http://www.R-project.org

Rabinowitz D (1981) Seven forms of rarity. In Synge H (eds) The biological aspects of rare plant conservation. John Wiley \& Sons, New York, pp 205-217 
Rameau JC, Mansion D, Dume G, Gauberville C (2008) Flore Forestière Française. Guide écologique illustré. Région méditerranéenne. IDF, Paris

Rossetto M, Kooyman RM (2005) The tension between dispersal and persistence regulates the current distribution of rare palaeo-endemic rain forest flora: a case study. $J$ Ecol 93:906-917

Sáez L, Montserrat JA, Rosselló JA (2002) A new subspecies of Arenaria grandiflora (Caryophyllaceae) from the Rif mountains (northern Morocco). Folia Geobot 37:339-349

Silvertown J, Dodd M (1996) Comparing plants and connecting traits. Philos Trans, Ser B 351:1233-1239

Silvertown J, Dodd M, Gowing D (2001) Phylogeny and the niche structure of meadow plant communities. $J$ Ecol 89:428-435

Soininen J, Heino J (2007) Variation in niche parameters along the diversity gradient of unicellular Eukaryote Assemblages. Protist 158:181-191

Stebbins GL, Major J (1965) Endemism and Speciation in California Flora. Ecol Monogr 35:1-35

Swofford DL (2003) PAUP*. Phylogenetic Analysis Using Parsimony (*and Other Methods). Version 4. Sinauer Associates, Sunderland, Massachusetts

Tamura K, Dudley J, Nei M, Kumar S (2007) MEGA4: Molecular Evolutionary Genetics Analysis (MEGA) software version 4.0. Molec Biol Evol 24:1596-1599

Tatoni T, Médail F, Roche P, Barbero M (2004) The impact of changes in land use on ecological patterns in Provence (Mediterranean France). In Mazzoleni S, Di Pascale G, Di Martino P, Rego F, Mulligan M (eds) Recent dynamics of Mediterranean vegetation and landscape. John Wiley \& Sons, London, pp 107-120

Thioulouse J, Chessel D, Dolédec S, Olivier JM (1997) ADE-4: A multivariate analysis and graphical display software. Statistics and Computing 7:75-83

Thompson JD (2005) Plant evolution in the Mediterranean. Oxford University Press, New York

Thuiler W, Lavorel S, Midgley G, Lavergne S, Rebelo T (2004) Relating plant traits and species distribution along bioclimatic gradients for 88 Leucadendron taxa. Ecology 85:1688-1699

Tremetsberger K, Weiss-Schneeweiss H, Stuessy T, Samuel R, Kadlec G, Ortiz MA, Talavera S (2005) Nuclear ribosomal DNA and karyotypes indicate a NW African origin of South American Hypochaeris (Asteraceae, Cichorieae). Molec Phylogen Evol 35:102-16

Tribsch A, Schönswetter P (2003) Patterns of endemism and comparative phylogeography confirm palaeoenvironmental evidence for Pleistocene refugia in the Eastern Alps. Taxon 52:477-497

Tsiftsis S, Tsiripidis I, Karagiannakidou V, Alifragis D (2008) Niche analysis and conservation of the orchids of east Macedonia (NE Greece). Acta Oecol 33:27-35

Valcárcel V, Vargas P, Nieto Feliner G (2006) Phylogenetic and phylogeographic analysis of the western Mediterranean Arenaria section Plinthine (Caryophyllaceae) based on nuclear, plastid, and morphological markers. Taxon 55:297-312

Valente LM, Savolainen V, Vargas P (2010) Unparalleled rates of species diversification in Europe. Proc Roy Soc London 277:1489-1497

Véla E, Auda P, Léger JF, Gonçalves V, Baumel A (2008) Exemple d'une nouvelle évaluation du statut de menace suivant les critères de 1'UICN version 3.1.: le cas de l'endémique provençale Arenaria provincialis Chater \& Halliday (= Gouffeia arenarioides DC., Caryophyllaceae). Acta Bot Gallica 155:547-562

Venable DL, Lawlor L (1980) Delayed germination and dispersal in desert annuals: Escape in space and time. Oecologia 46:272-282

Verlaque R, Médail F, Quézel P, Babinot JF (1997) Endémisme végétal et paléogéographie dans le bassin méditerranéen. Geobios 21:159-166

Walck JL, Baskin JM, Baskin CC (2001) Why is Solidago shortii narrowly endemic and S. altissima geographically widespread? A comprehensive comparative study of biological traits. J Biogeogr 28:1221-1237

Walter KS, Gillet HJ (eds) (1998) 1997 IUCN Red List of Threatened Plants. Compiled by the World Conservation Monitoring Centre, IUCN (The World Conservation Union), Gland and Cambridge

Webb TJ, Gaston KJ (2003) On the heritability of geographic range sizes. Amer Naturalist 161:553-566

Wyse Jackson MB, Parnell JA (1987) A biometric study of the Arenaria ciliata L. complex (Caryophyllaceae). Watsonia 16:373-382

Youssef S, Véla E, Baumel A, Tatoni T (2010) Distribution, habitat and population size variation of Genista lobelii (Fabaceae) from the limestone mountains of Basse Provence (S-E France). Ecol Medit $36: 63-76$

Received: 10 June 2010 /Revised: 12 November 2010 / Accepted: 3 January 2011 /

Published online: 25 May 2011 